\title{
QUANTITATIVE PARAMETERS OF ANTI-MONEY LAUNDERING REGULATION"
}

\author{
Nataliya Yu. TANYUSHCHEVA
}

Astrakhan State University (ASU),

Astrakhan, Russian Federation

n.tanyushcheva@yandex.ru

https://orcid.org/0000-0002-7277-7316

\section{Article history:}

Article No. 480/2020

Received 3 August 2020

Received in revised form

21 September 2020

Accepted 5 October 2020

Available online

25 December 2020

JEL classification: E26, F38, G28

\section{Keywords:}

financial digitization, money laundering, AML, fixed limit of transaction (FLT), fixed limit of cash transaction (FLCT), G-20

\begin{abstract}
Subject. As financial institutions carry out a huge number of transactions, the financial sector definitely needs to automate some control procedures, including anti-money laundering ones. The effectiveness of automated control measures directly depends on how adequately tasks for the software are written. The article examines the impact of macroeconomic indicators, such as GDP per capita, average wage, and the scale of the shadow economy in the G20 countries and in two of the CIS countries (Belarus and Tajikistan) on thresholds of the fixed limit of transaction (FLT), which is regulated with the anti-money laundering legislation, including the fixed limit of cash transaction (FLCT).

Objectives. I investigate approaches to setting FLT (FLCT) in different countries and formulate my opinion on this issue.

Methods. The methodological basis of the study was made up of empirical and logical constructions, statistical analysis, synthesis, systems approach.

Results. I identified why FLT (FLCT) are denied. This happens due to lawmakers' confidence in the effectively controlled financial sector, or the corruption pressure. The countries with FLT (FLCT) introduce and use them formally. The article presents the risk-based approach to measuring the FLCT based on the macroeconomic indicators (average annual wages, savings per capita).

Conclusions and Relevance. The case of Russia shows that the inflation undermines the barrier function of FLT (FLCT), while the analytical division of financial intelligence has to handle more issues. The proposed approach will help reduce costs the financial system incurs to process financial information in order to counter money laundering.
\end{abstract}

(c) Publishing house FINANCE and CREDIT, 2020

Please cite this article as: Tanyushcheva N.Yu. Quantitative Parameters of Anti-Money Laundering Regulation. Digest Finance, 2020, vol. 25, iss. 4, pp. 416-429.

https://doi.org/10.24891/df.25.4.416

\section{Introduction}

The financial system came across anti-money laundering (AML) while being digitalized. Advances in digital technologies largely determine the development of both the financial

\footnotetext{
" The study was supported by the Russian Foundation for Basic Research (RFBR), project № 20-010-00243A.

Статья выполнена при поддержке Российского фонда фундаментальных исследований (РФФИ), проект № 20-010-00243A.
} 
sector and the international anti-money laundering movement. In the face of trillions of transactions every day, an active fight against money laundering requires financial organizations, primarily banks, to quickly and reliably protect themselves from involvement into the money laundering process.

The Know Your Customer (KYC) procedures demonstrate the highest degree of digitalization. KYC standards are developed by the legislature in some countries. For example, Russia has the Unified Identification and Authentication System and the Unified Biometric System that collects and stores personal data about citizens and provides authorized access to such data, including financial organizations.

Most modern professional educational AML programs operate in the digital environment.

The identification of suspicious operations (transactions) and money laundering schemes by financial organizations is a relatively new area of digitalization in AML. Detection results largely depend on the quality of input parameters of analytical applications to computer software.

In the first version of the 40 FATF Recommendations, countries were to consider the possibility and usefulness of a system in which banks and other financial institutions and intermediaries account on all transactions in national and foreign currencies above a fixed amount to a central national agency that has a computerized database available to competent authorities for use in money-laundering cases ${ }^{1}$.

Many countries have introduced FLT for various financial transactions. Most often, FLTs are established for transactions with real estate, precious metals, derivative financial instruments, works of art, etc. In Argentina, anti-money laundering laws apply to actions concealing sources of funds exceeding ARS 50,000 and more. Although a smaller amount, the same acts are classified as concealment, recognized as less serious crime and removed from the AML system. However, most countries set FLCM, in particular, for the purchase and sale of foreign currency in cash, cross-border transfers, transactions with prepaid financial products purchased with cash, and others.

The essence of the money laundering process, which pursues making criminal proceeds look like legally earned funds, determines the scale of difficulties faced by the anti-money laundering movement. Money laundering differs significantly from the shadow economy, which is really embodied through tools and finished products or works (services) delivered. The shadow economy leaves a tangible footprint, such as electricity overspending, growing money supply, etc., which makes it possible to apply mathematics in analytical and regulatory schemes and to digitalize control. All this is not about money laundering, which exists through flows and transformation of money and other financial assets. Accordingly, underlie mathematical methods of the AML regulation, axioms seem to be a methodological problem.

\footnotetext{
${ }^{1}$ The Forty Recommendations of the Financial Action Task Force on Money Laundering. FATF. 1990. URL: https://www.fatf-gafi.org/media/fatf/documents/recommendations/pdfs/FATF\%20Recommendations\%201990.pdf
} 
Meanwhile, economists have already taken some efforts to find the axioms. G. Becker, the founder of the neoclassical interpretation of crime and punishment, formulated an economic model of criminal behavior in a logically strict mathematical format [1]. Of interest are Becker's arguments that, as the economic situation in the country and the performance of law enforcement agencies improve, the propensity to crime generally decreases [2].

Becker's followers expanded the field for crime research with mathematical tools. Thus, A. Ehrlich formulated parameters for evaluating the effectiveness of law enforcement agencies and associated costs incurred by the public [3]. Later, M. Reynolds delved into optimizing the distribution of police resources. He was interested in the question of redistributing law enforcement expenditures among different crimes as well as the financing of labor and investment in the means of fighting crime [4]. According to M. Reynolds, governments should redistribute costs for anti-money laundering activities, their commencement and development within their consolidated budgets.

In general, according to the theory of crime and punishment, a growth in wealth and AML costs contributes to the effectiveness of such a fight.

However, FATF's national anti-laundering system reports show that these are countries demonstrating the high standard of living and effective law enforcement systems and housing global financial centers and major centers of international banking that are used... to launder the proceeds of major foreign crimes, including transnational organized crime and corruption abroad ${ }^{2}$.

Scientists do not consider Becker's model perfect either. According to T. Orsagh and D. Witte, the theory of crime and punishment predicts the relationship between the economic situation in the country and crime only in special conditions [5, p. 1069].

Another focus of economic research is the role of money in the shadow economy. Developing a monetary approach to assessing the extent of informal activities, some U.S. economists have justified the position that cash serves as means of payment in the shadow economy [6-8]. As a follow-up to this provision and in accordance with practice, it is generally recognized that most money laundering schemes involve the use of cash by criminals [9].

Both money laundering models known to researchers, i.e. foreign one (dirty cash deposited to with banks) ${ }^{3}$ and the Russian one (illegally rejected non-cash funds of the budget or large companies' money are legalized through cashing), imply the process of losing money trails [10], during which excess profits are split so as to overcome anti-laundering procedures [11].

\footnotetext{
${ }^{2}$ Mutual Evaluation Report of the United Kingdom. Executive Summary. FATF. 2018. URL: https://www.fatfgafi.org/media/fatf/documents/reports/mer4/MER-United-Kingdom-2018-Executive-Summary.pdf

${ }^{3}$ Zünd A. Geldwäscherei, Motive - Formen - Abwehr. Der Schweiser Treuhänder, 1990, 64. Jg., Nr. 9, pp. 403-408; Müller C. Geldwäscherei: Motive - Formen - Abwehr. Eine betriebswirtschaftliche Analyse, TreuhandKammer, Zürich, 1992.
} 
Currently, the complete withdrawal from cash circulation, even for countering money laundering and the shadow economy in general, is considered premature. As V. Ionov holds, the world's leading economies continue to vigorously develop cash circulation [12, p. 50]. Economists have been searching for the optimal ratio of cash in circulation [13]. Econometric modeling of money laundering through the demand for cash is actively developing $^{4}[14]$.

However, none of these theories can answer how to determine an amount to which criminals might split illegal proceeds during their legalization. It is logical to assume that, on the one hand, the amount cannot be infinitesimal, since the final cost of laundering procedures increases as more transactions are made. On the other hand, the amount should not be captured by anti-money laundering procedures, looking like a common financial transaction in a region (country) in a certain period of time. As the practice shows, criminals adjust money laundering technologies to the FLCT threshold.

Thresholds are widely used in risk management for limitation purposes. Meanwhile, there are not yet tools for the threshold-setting methodology. Some studies have recently started concerning threshold values based on the aggregate theory recently $[15,16]$. This method requires substantial databases, which are unavailable for countermeasures.

As for public costs of AML control, upon the introduction of FLT, costs of the private financial sector are shared to a certain extent with the State, which undertakes to process and analyze a great deal of information on major financial transactions. Lowering the FLT should increase costs of both the financial sector and the State and vice versa.

\section{Constant FLT (FLCT)}

Constant FLT (FLCT) is the regulated minimum value of a financial transaction that is legally established and expressed in monetary terms.

In 1970, the United States passed the Bank Secrecy Act (1970), which required regulated financial institutions to record cash transactions. If the transaction totally exceeded USD 10,000, they were to inform the financial crime department (FinCEN) of such a transaction(s) and its parties within a business day. On the eve of the adoption of the law, in 1969, the average salary in the United States was USD 9,430 per year ${ }^{5}$. Consequently, the FLT was comparable to the annual average per capita earnings in the legal economy.

As shown in Table 1, three countries of G20 have not introduced the FLT, with Japan being among them. Japan is a highly developed market economy, having the lowest crime rates, focusing on gambling, pornography and usury. No terrorist financing has been recorded, and

\footnotetext{
${ }^{4}$ Deutsche Bundesbank. Cash Demand in the Shadow Economy. Monthly Report. March 2019, pp. 43-58. URL: https://www.bundesbank.de/resource/blob/793190/466691bce4f27f76407b35f8429441ae/mL/2019-03-bargelddata.pdf

${ }^{5}$ Consumer Income. Current Population Reports. U.S. Department of Commerce. Series P-60. No. 70. July 16, 1970. URL: https://www2.census.gov/library/publications/1970/demographics/p60-70.pdf
} 
the FATF positively assesses the effectiveness of the country's anti-laundering system ${ }^{6}$ [17]. Hence, it is possible to assume that the high level of financial technologies, including digital ones, and traditional national discipline help the State to delegate the current anti-money laundering control to regulated financial institutions without compromising its effectiveness in terms of national interests and the FATF standards.

On the contrary, in Saudi Arabia, the anti-laundering system is catching up. In the economy based mainly on the oil industry and a poorly developed financial system, the main types of the shadow economy are recognized as terrorist financing, drug trafficking, and corruption ${ }^{7}$. Presumably, the rejection of FLT is due to the active intervention of governing bodies into regulated financial institutions and, accordingly, the loyalty of the State to these organizations in relation to anti-money laundering control, while the FATF is not involved.

Turkey has made an economic and investment breakthrough for the recent two decades, but the continuing instability strongly engenders the shadow economy, mainly in drug trafficking, smuggling, tax evasion, corruption, and the production of counterfeit goods. In 2010-2014, the country was on the list of the FATF recognized jurisdictions with strategic shortcomings in anti-laundering. Being threatened with financial sanctions, the antilaundering system was reformed, but FLT was not introduced.

Subsequently, the proposal for countries to establish FLT was removed from international anti-laundering standards. In general, countries that reject the FL are at different stages of their economic development and demonstrate different economic structures, composition and scale of the shadow sector. What they have in common is the State being confident in the national financial sector. Such confidence differs in each case: low crime rates and sophisticated financial controls in Japan, affiliation in Saudi Arabia, and corruption in Turkey.

In those countries, where FLT is in place, no general patterns of its definition have been identified. There is no correlation between FLT and such macroeconomic indicators as GDP per capita, the scale of the shadow economy, and the average annual salary. The average GDP per capita in the United States is only 19 percent as high as in Germany, but the U.S. FLT is 75-fold higher than the German one. The shadow economy in Germany is greater than in the UK by 0.9 percent, while the German FLT is twice as low as the British one. In Mexico and Argentina, GDP per capita is at the same level but Argentina's GDP is 2.4 times higher. The scale of the shadow economy has similar indicators in Indonesia and Argentina, but the Indonesian FLT is almost six-fold higher than the Argentinian one.

As seen in Table 2, four G20 countries (Argentina, Saudi Arabia, Turkey, Japan) have not set the FLT due to reasons discussed above.

\footnotetext{
${ }^{6}$ Mutual Evaluation of Japan. FATF. 2008.

URL: https://www.fatf-gafi.org/countries/j-m/japan/documents/mutualevaluationofjapan.html

${ }^{7}$ Mutual Evaluation Report. Kingdom of Saudi Arabia. Anti-Money Laundering and Counter-Terrorist Financing Measures. MENAFATF. 2018. URL: https://www.fatf-gafi.org/media/fatf/documents/reports/mer/MER-Saudi-Arabia2018.pdf
} 
According to the FATF, Argentina launders large amounts of cash generated by cross-border criminal organizations that stem from the deep-rooted crime in drug transit and human trafficking $^{8}$. The FLT has been possibly rejected due to the corrupt interference of criminal groups in the anti-laundering regulation nationwide. As the FATF has revealed during its recent inspection in Argentina, the country has significant shortcomings in the national antilaundering system.

Thus, the G20 countries without the FLT differ by their economic development level, financial system, public well-being and the scale of the shadow economy. This FLT rejection shifts the focus of the anti-money laundering burden towards regulated financial institutions, freeing up budgetary resources for other tasks. At the same time, authorities do admit that if the FATF recognizes significant shortcomings in the national anti-laundering system, the damage to the national financial system and budget can be fatal.

Although a common motive for the FLT (FLCT) rejection has been found, determining patterns are not yet traced. As showed in Table 2, average annual wages in 2018 (AAW) in China was almost twice as low as in Mexico, while the FLCT to AAW ratio in China was 47-fold higher. Among advanced economies, similar AAW was recorded in France and the United States, i.e. USD 48,612 and USD 48,768 respectively. However, the FLT to AAW ratio in the USA is more than tenfold higher than in France.

Thus, the countries decide to introduce and establish the FLT (FLCT) without carrying out any scientific analysis.

\section{Joint FLT (FLCT)}

The constant FLT is not used by all the countries. There is a practice of applying FLT related to macroeconomic indicators. For example, in the Republic of Belarus, FLT and FLCT are set as high as basic values established by the law?

According to Fig. 1, in 2002-2019, there was a noticeable convergence of FLT and AAW in the Republic of Belarus. Considering the economic growth and a decrease in crime, this convergence has caused an increase in the burden on the financial intelligence department of the Republic of Belarus, since regulated financial institutions produced more intensive reporting on cash transactions from. In terms of the risk-based approach, such a burden seems unreasonable. In 2019, experts of the Eurasian group, which resembles the FATF, noted the country practices the formal approach to anti-money laundering regulation, pointing out that the national risks of money laundering were not determined on the basis of high-quality and comprehensive information ${ }^{10}$.

\footnotetext{
${ }^{8}$ Mutual Evaluation of Argentina. 11th Follow-up Report. FATF. 2014. URL: http://www.fatf-gafi.org/media/fatf/documents/reports/mer/FUR\%20Argentina_reduced.pdf

${ }^{9}$ The basic value is defined as an indicator for calculating pensions, allowances, taxes, fees, and penalties, established by the government of the Republic of Belarus since 2002. This indicator is established instead of the minimum wage.

${ }^{10}$ Mutual Evaluation Report of the Republic of Belarus. EAG. 2019. URL: https://www.fatf-gafi.org/media/fatf/documents/reports/mer-fsrb/EAG-Mutual-Evaluation-Report-Belarus2019.pdf
} 
Tajikistan is another country with joint FLT (FLCT), where anti-laundering thresholds are expressed through a legally established number of indicators for calculation (IfC). There are several values of FLT for various financial operations and transactions (80, 350, 1750, 12,500 IfC), FLCT for purchase-sale transactions in foreign currency is 350 IfC (Fig. 2).

As showed in Fig. 2, Becker's rational model was not found to work in Tajikistan. Although the economic situation improves, the crime rate fails to decrease. As official comments are missing, there is an assumption that the convergence of FLT and AAW is due to the desire of lawmakers to clarify the role of the currency exchange operations in money laundering schemes in the country.

To sum up, joint FLT (FLCT), as well as constant ones, are introduced and used without a proper theoretical justification.

Being classified by their form (constant and joint), FLT and FLCT can also be grouped by degree of stability - stable, decreasing and increasing. Stable ones are observed in the USA, Russia (for regulated cash transactions and bank account transactions) and a number of other countries that have kept their indicators unchanged since their introduction. Decreasing indicators are typical, for example, of the European Union and China. Increasing indicators are less frequent. For example, in Russia, FLT for real estate transactions was increased from RUB 1 to 3 million.

\section{FLT (FLCT) in Russia}

According to the proposed classification, the Russian Federation should be attributed to the countries with constant and mostly stable FLT and FLCT. Most of the anti-laundering thresholds, including FLCT, were set in 2001 as much as RUB 600,000. Just before the adoption of the Russian Anti-Money Laundering Law, which established FLT and FLCT, the AAW in Russian was RUB 26,676 ${ }^{11}$, i.e. 22.5 times higher than FLT (FLCT). The composition of FLT is periodically expanded, but the threshold of 600,000 RUB has remained unchanged.

To study the environment of the Russian FLT (FLCT)s, the GDP growth rate was compared to that of indicators that characterize crime in the country and damage from crime from 2011 to 2018 (Fig. 3).

As seen in Fig. 3, as GDP grows, quantitative indicators of crime decrease, and economic crime indicators decline at a faster pace. However, the damage from an average crime showed an increase, which is mostly manifested in economic crime. The result confirms Becker's rational choice theory [1]. According to the rational choice theory, the improving well-being positively influences the propensity of individuals to legitimate activities. The

\footnotetext{
${ }^{11}$ Labor Market, Employment and Wages. Average Monthly Nominal Wage Accrued to Employees by Constituent Entity of the Russian Federation, 2000-2013. Federal State Statistics Service, 2020.

URL: https://www.gks.ru/labor_market_employment_salaries (In Russ.)
} 
law breaking tendency is observed among individuals seeking super-high incomes, which are subject to laundering schemes.

As part of the risk-based approach, it is advisable to formalize transaction detection procedures with respect to activities, entities or assets exposed to the high risk of money laundering.

Thus, according to the National AML risk assessment for Russia ${ }^{12}$, cash transactions are exposed to the high risk level, but this level is reduced due to the consistent measures curbing the unreasonable cash turnover.

Financial organizations detect transactions, not subject to thresholds, using the software tracing large and/or regular transactions. FLT (FLCT) applies to transactions reported to the national financial intelligence service (in Russia, this is Federal Financial Monitoring Service - FFMS), which aggregates information about random high-risk transactions and identifies ties that are invisible for a separate financial organization. As a rule, antilaundering procedures scrutinize transactions that are as similar as possible to normal legal activities.

According to the FATF mutual evaluation report on Russia's AML system, limit amounts signaled as suspicious transactions are low, and the automation of the process leads to a great deal of messages... They do not contain details raising serious suspicions or requiring the urgent interference ${ }^{13}$. The excessive number of messages not only increases expenses incurred by the Federal Financial Monitoring Service and the private financial sector, but also hinders business processes of bona fide economic entities.

Cash transactions subject to FLCT set by the Russian Anti-Money Laundering Law mostly relate to individuals. These include the purchase and sale of foreign currency in cash, purchase of securities, cashing bearer checks from non-residents, fiat money exchange and contribution of funds to the authorized (pooled) capital. Such transactions are out of households' routine, but take place occasionally due to various circumstances when individuals manage their income and/or savings.

To define FLT, we suggest using a simple formula:

$$
F L C T=(A A W+S P C) \cdot \alpha,
$$

where AAW is the average annual wage, RUB;

SPC mean savings per capita, RUB;

\footnotetext{
${ }^{12}$ National Assessment of AML Risks: Key Findings. 2018. Public Report. Federal Financial Monitoring Service. URL: http://www.fedsfm.ru/nationalocenka (In Russ.)

${ }^{13}$ Mutual Evaluation Report. Anti-Money Laundering and Counter-Terrorist Financing Measures. Russian Federation. FATF-EAG, 2019, p. 7. URL: https://www.fatf-gafi.org/publications/mutualevaluations/documents/mer-russianfederation-2019.html
} 
$\alpha$ is a coefficient of the relationship between FLCT and other macroeconomic indicators other than AAW and SPC.

As of July 1, 2020, the Federal State Statistics Service released current reports on the average monthly wage of employees (AAW = RUB 584.2 thousand) ${ }^{14}$, savings, such deposits in RUB, cash balances and securities, with reference to the number of population. The data are extrapolated to GDP trends, helping estimate savings as much as RUB 197.5 thousand ${ }^{15}$. $\alpha$ stands for any changes in the economy and financial sector that might considerably influence bona fide households while making their marketable resources, which are not included into official statistics. For example, balance of e-money, legitimate investment in cryptocurrency (virtual money). Let us take $\alpha$ to equal 1 , given profound changes in the global and national economies and serious restrictions, unavailable information about a new financial resource of households, besides the average annual wage and savings per capita. However, the value of $\alpha$ may change at different phase of an economic cycle. The estimated FLCT is RUB 800 thousand.

The increased FLCT should not in any way be considered as the softening of the antilaundering policy. This decision should be made based on a stable trend in the time interval. In the case of FLT (FLCT), the 5-year interval seems reasonable, as defined by the FATF standards for storing data on random transactions. The severe financial and economic crisis or rapid economic growth can induce the revision of FLCT, since they considerably change the AAW and SPC.

In Russia, there is also a RUB 3,000,000 FLT for real estate transactions, RUB 100,000 FLT for non-profit organizations' deals, and a RUB 10,000,000 FLT for strategic enterprises' transactions. The proposed algorithm for FLCT can also be used to reevaluate them.

\section{Conclusion}

The article unfolds the AML regulation theory, considering the State and the private financial sector sharing the burden of detecting money laundering transactions by determining the optimal value of regulated thresholds for the fixed limit of transactions (FLT). The notion of FLT is introduced, their classification is given. I investigate why some G20 countries choose to reject the FLT. I prove that the rejection may be appropriate only if the following conditions are met simultaneously:

- low crime rate;

- a highly developed financial system based on digitalization, with its participants being independently and effectively protected from the penetration of the shadow capital.

\footnotetext{
${ }^{14}$ Labor Market, Employment and Wages. Average Monthly Nominal Wage Accrued to Employees by Constituent Entity of the Russian Federation, 2013-2019. Federal State Statistics Service, 2020.

URL: https://www.gks.ru/labor_market_employment_salaries (In Russ.)

${ }^{15}$ Volume and Composition of People’s Monetary Savings. Federal State Statistics Service, 2020. URL: https://rosstat.gov.ru/free_doc/new_site/population/urov/doc3-1-2.htm (In Russ.)
} 
Such requirements exist in Japan. Other countries (Argentina, Saudi Arabia, Turkey) decline the FLT, since the corruption and respective informal power influence the legislative process.

In the G20 countries, the Republic of Belarus and Tajikistan, which use FLT, I did not discover any relationship of threshold values and macroeconomic indicators and the shadow economy. Countries set them formally.

Illustrating cash operations classified as exposed to the high money laundering risk, I consider whether it is possible to determine the FLT for a single transaction, not captured by AML procedures of financial institutions. The proposed formula for calculating FLCT allows taking into account both macroeconomic indicators and other factors, such as crime, money supply structure, etc. While negative macroeconomic symptoms intensify, such as a rise in inflation, unemployment, and a decrease in the correction coefficient, financial intelligence will quickly receive more information about high-risk financial transactions and quickly indicate new threats to law enforcement and supervisory authorities for their early elimination. On the contrary, during the economic recovery in the country and improving well-being of the public, the increased FLT will alleviate the burden on financial intelligence, allow redistributing budgetary funds to develop the economy or improve the social security.

Table 1

FLT and GDP per capita in the G20 countries as of January 1, 2019

\begin{tabular}{|c|c|c|c|c|c|}
\hline Country & $\begin{array}{l}\text { GDP per capita } \\
\text { (PPP), 2018, } \\
\text { USD }\end{array}$ & $\begin{array}{l}\text { FLT, } \\
\text { national } \\
\text { currency, } \\
\text { description }\end{array}$ & $\begin{array}{l}\text { FLCT, } \\
\text { USD }\end{array}$ & $\begin{array}{l}\text { FLT to GDP } \\
\text { per capita ratio } \\
(4 / 2) \cdot 100, \%\end{array}$ & $\begin{array}{l}\text { Shadow } \\
\text { economy } \\
\text { scale, } \\
\% \text { of GDP }\end{array}$ \\
\hline \multicolumn{6}{|c|}{ Advanced Economies } \\
\hline USA & 62,605592 & USD 10,000 & 10,000 & 15.97 & 8.34 \\
\hline Germany & $52,558.690$ & EUR 1,000 & 1,178 & 2.24 & 11.97 \\
\hline Australia & $52,373.460$ & AUD 1,000 & 745 & 1.42 & 12.06 \\
\hline Canada & $49,651.176$ & CAD 10,000 & 7,703 & 15,51 & 13.92 \\
\hline France & $45,775.149$ & EUR 1,000 & 1,178 & 2.57 & 14.08 \\
\hline United Kingdom & $45,704.621$ & EUR 2,000 & 2,356 & 5.15 & 11.08 \\
\hline Japan & $44,227.159$ & FLT not set & FLT not set & FLT not set & 10.41 \\
\hline South Korea & $41,350.588$ & KRW 1,000,000 & 849 & 2.05 & 25.7 \\
\hline Italy & $39,636.989$ & EUR 1,000 & 1,178 & 2.97 & 24.95 \\
\hline \multicolumn{6}{|c|}{ Developing Economies } \\
\hline Saudi Arabia & $55,943.861$ & FLT not set & FLT not set & FLT not set & 16.65 \\
\hline Russia & $29,266.855$ & RUB 600,000 & 9,535 & 32.58 & 38.42 \\
\hline Turkey & $27,956.092$ & FLT not set & FLT not set & FLT not set & 31.38 \\
\hline Mexico & $20,601.660$ & USD 500 & 500 & 2.42 & 31.74 \\
\hline Argentina & $20,537.060$ & ARS 50,000 & 1,200 & 5.84 & 24.14 \\
\hline China & $18,109.810$ & CNY 50,000 & 7,474 & 41.27 & 14.67 \\
\hline Brazil & $16,154.326$ & BRL 10,000 & 2,731 & 16.91 & 37.63 \\
\hline South Africa & $13,675.341$ & ZAR 25,000 & 1,888 & 13.80 & 25.94 \\
\hline Indonesia & $13,229.544$ & IDR $100,000,000$ & 7,008 & 52.97 & 24.11 \\
\hline India & $7,873.725$ & INR 50,000 & 7,288 & 9.26 & 23.91 \\
\hline
\end{tabular}

Source: GDP per capita (PPP), 2018. USD: World Economic Outlook Database April 2019. International Monetary Fund. URL: https://www.imf.org/external/pubs/ft/weo/2019/01/weodata/index.aspx; 
FLT, national currency, characteristic are based on national anti-money laundering laws; FLT, USD are calculated by the author with reference to the average annual exchange rates of national currencies to the USD, 2018, Thomson Reuters; Scale of the shadow economy, \% of GDP are based on materials published by Medina L., Schneider F. Shadow Economies Around the World: What Did We Learn Over the Last 20 Years? IMF Working Paper, 2018. URL: https://www.imf.org/en/Publications/WP/Issues/2018/01/25/ShadowEconomies-Around-the-World-What-Did-We-Learn-Over-the-Last-20-Years-45583

\section{Table 2}

FLCT and remuneration in the G20 countries as of January 1, 2019

\begin{tabular}{|c|c|c|c|c|}
\hline Country & $\begin{array}{l}\text { Average annual } \\
\text { wage, national } \\
\text { currency }\end{array}$ & $\begin{array}{l}\text { Average annual } \\
\text { wage, } \\
\text { USD }\end{array}$ & $\begin{array}{l}\text { FLCT, national } \\
\text { currency }\end{array}$ & $\begin{array}{l}\text { FLCT ratio to } \\
\text { average annual } \\
\text { wage } \\
(4 / 2) \cdot 100, \%\end{array}$ \\
\hline India & INR 200,700 & 2,868 & $\begin{array}{l}\text { INR } 1,000,000 \text {, } \\
\text { individual operations }\end{array}$ & 498.26 \\
\hline Indonesia & IDR 50,4 million & 3,456 & $\begin{array}{l}\text { IDR } 100,000,000 \text {, } \\
\text { individual operations }\end{array}$ & 198.41 \\
\hline Turkey & TRY $16,560-33,960$ & $3,144-6,444$ & FLCT not provided & FLCT not provided \\
\hline Mexico & MXN 93,552 & 4,752 & $\begin{array}{l}\text { MXN 9,843 } \\
\text { (USD 500), } \\
\text { Total }\end{array}$ & 10.52 \\
\hline Brazil & BRL 27,048 & 6,972 & $\begin{array}{l}\text { BRL 10,000, } \\
\text { individual operations }\end{array}$ & 36.97 \\
\hline Russia & RUB 524,688 & 7,547 & $\begin{array}{l}\text { RUB } 600,000 \text {, } \\
\text { individual operations }\end{array}$ & 114.35 \\
\hline Argentina & ARS 422,988 & 11,040 & FLCT not provided & FLCT not provided \\
\hline China & CNY 82,464 & 11,988 & CNY 200,000, totally & 242.53 \\
\hline South Africa & ZAR 254,280 & 17,628 & ZAR 25,000, totally & 9.83 \\
\hline South Korea & KRW 37,200,000 & 31,596 & $\begin{array}{l}\text { KRW 10,000,000, } \\
\text { individual operations }\end{array}$ & 26.88 \\
\hline Great Britain & GBP 25,344 & 32,208 & $\begin{array}{l}\text { EUR 2,000 = } \\
\text { GBP 2,222, casino }\end{array}$ & 8.77 \\
\hline Japan & JPY 3,748,344 & 33,996 & FLCT not provided & $\begin{array}{l}\text { FLCT not } \\
\text { established }\end{array}$ \\
\hline Italy & EUR 33,000 & 37,740 & EUR 3,000, total & 9.09 \\
\hline Canada & CAD 54,192 & 39,756 & CAD 10,000, total & 18.45 \\
\hline Australia & AUD 56,592 & 39,864 & $\begin{array}{l}\text { AUD } 1,000 \text {, } \\
\text { individual operations }\end{array}$ & 1.76 \\
\hline France & EUR 42,504 & 48,612 & EUR 1,000, total & 2.35 \\
\hline USA & USD 48,768 & 48,768 & USD 10,000 , total & 20.51 \\
\hline Germany & EUR 47,256 & 54,048 & $\begin{array}{l}\text { EUR } 10,000 \text {, } \\
\text { individual operations }\end{array}$ & 21.16 \\
\hline Saudi Arabia & no data & no data & FLCT not provided & FLCT not provided \\
\hline
\end{tabular}

Source: Authoring based on the data of national currency exchange rates to USD, published by Thomson Reuters; South Africa Average Monthly Gross Wage, 2019. Trading Economics. URL: https://tradingeconomics.com/south-africa/wages; Average salary in India, 2019. Salary explorer. URL: http://www.salaryexplorer.com/salary-survey.php?loc=100\&loctype=1; Average per capita monetary income of the population in the Russian Federation, 2019. Federal State Statistics Service. URL: http://www.gks.ru/wps/wcm/connect/rosstat_main/rosstat/ru/statistics/population/level/\# (In Russ.) 


\section{Figure 1}

Dynamics of the ratio of FLT to AAW and the number of crimes per 100,000 people in the Republic of Belarus in 2002-2019

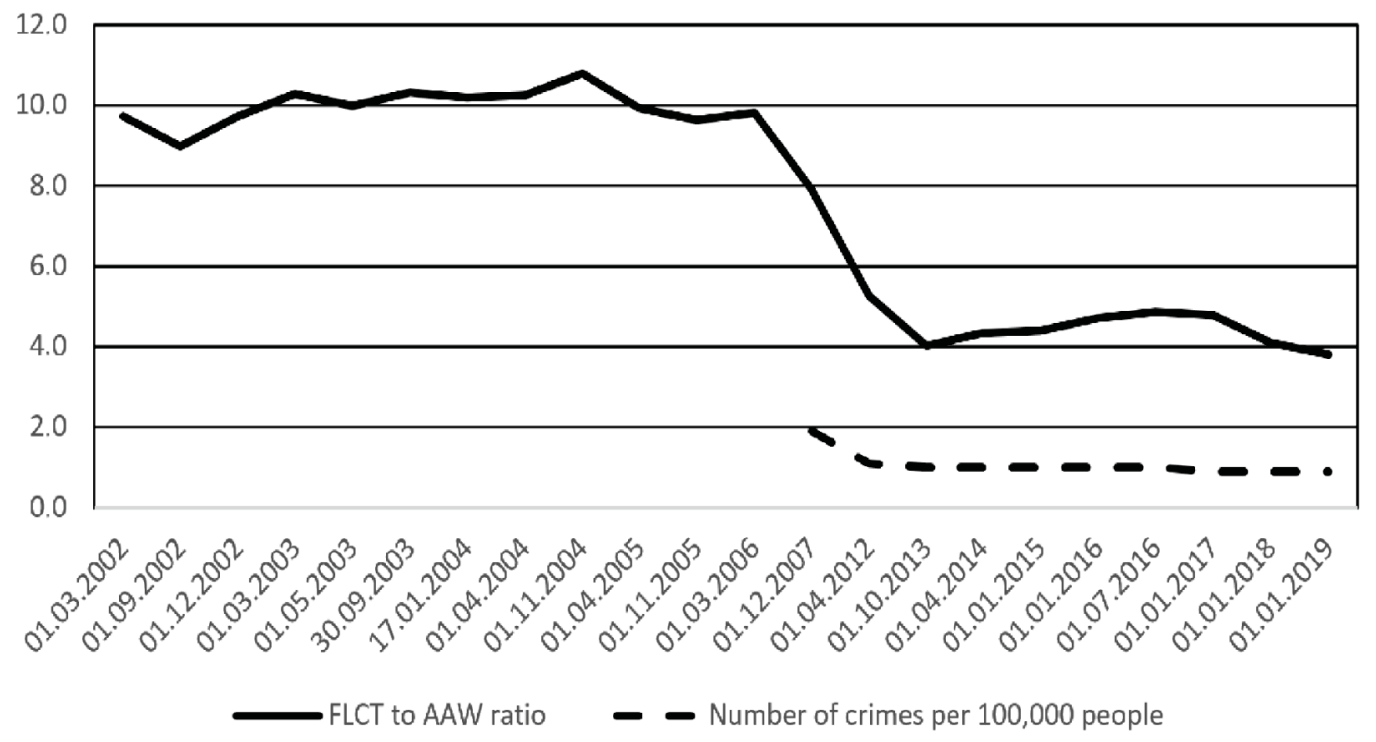

Source: Basic Unit. Taxes and Duties Ministry of the Republic of Belarus.

http://www.nalog.gov.by/ru/bazovaya-velichina/; Nominal accrued average wages of employees of the Republic of Belarus from 1991 to 2019. National Statistical Committee of the Republic of Belarus.

URL: http://www.belstat.gov.by/ofitsialnaya-statistika/solialnaya-sfera/trud/operativnaya-informatsiya_8/ zarabotnaya-plata/; the number of registered crimes. Official statistics. National Statistical Committee of the Republic of Belarus, 2020.

\section{Figure 2}

Dynamics of the ratio of FLCT to AAW and the number of crimes per 1,000 people in Tajikistan in 2002-2018

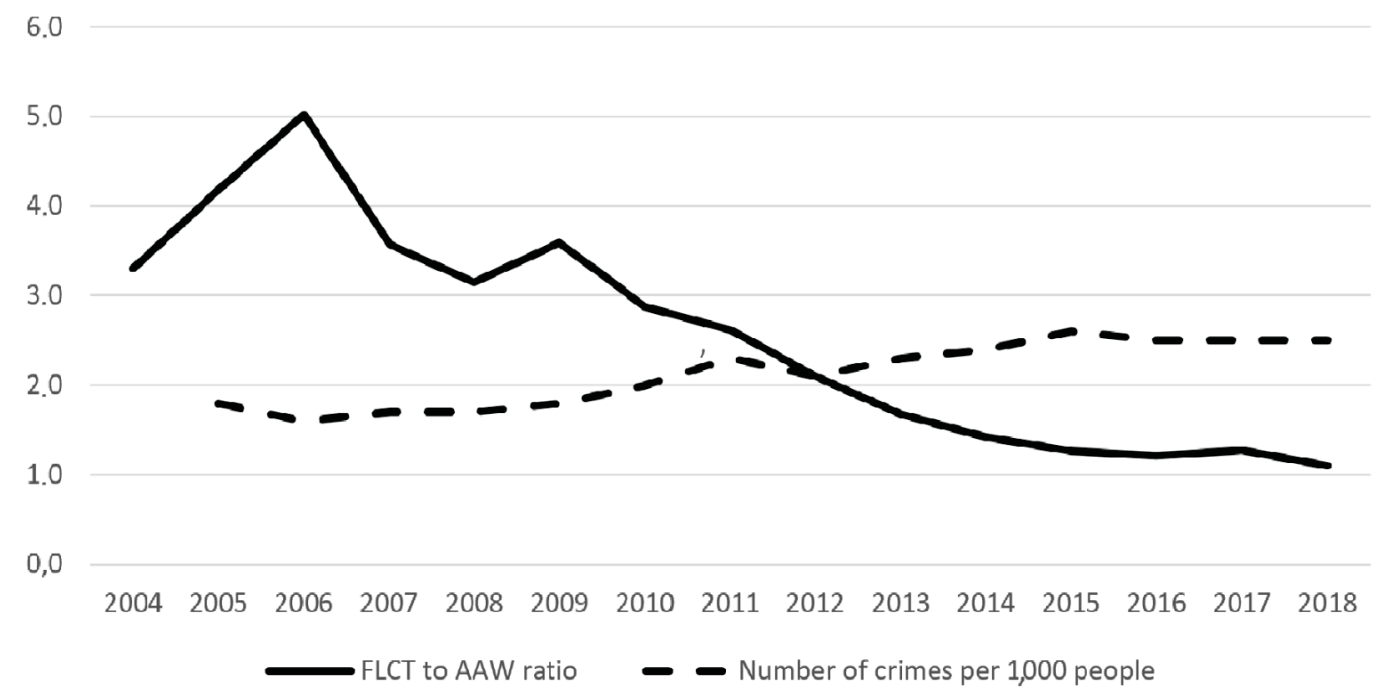

Source: Yuldashev R.R., Makhmadiev H.H., Akbarzoda A. A. Crime in Tajikistan (1991-2016): A scientific and practical guide. Dushanbe, KONTRAST Publishing House, 2018, p. 46; Socio-Economic Situation of the Republic of Tatarstan. Agency for Statistics under the President of the Republic of Tajikistan, 2018; Socio-Economic Situation of the Republic of Tajikistan in January 2019. Agency for Statistics under the President of the Republic of Tajikistan, 2019. 


\section{Figure 3}

The ratio of GDP growth and crime in Russia in 2011-2018
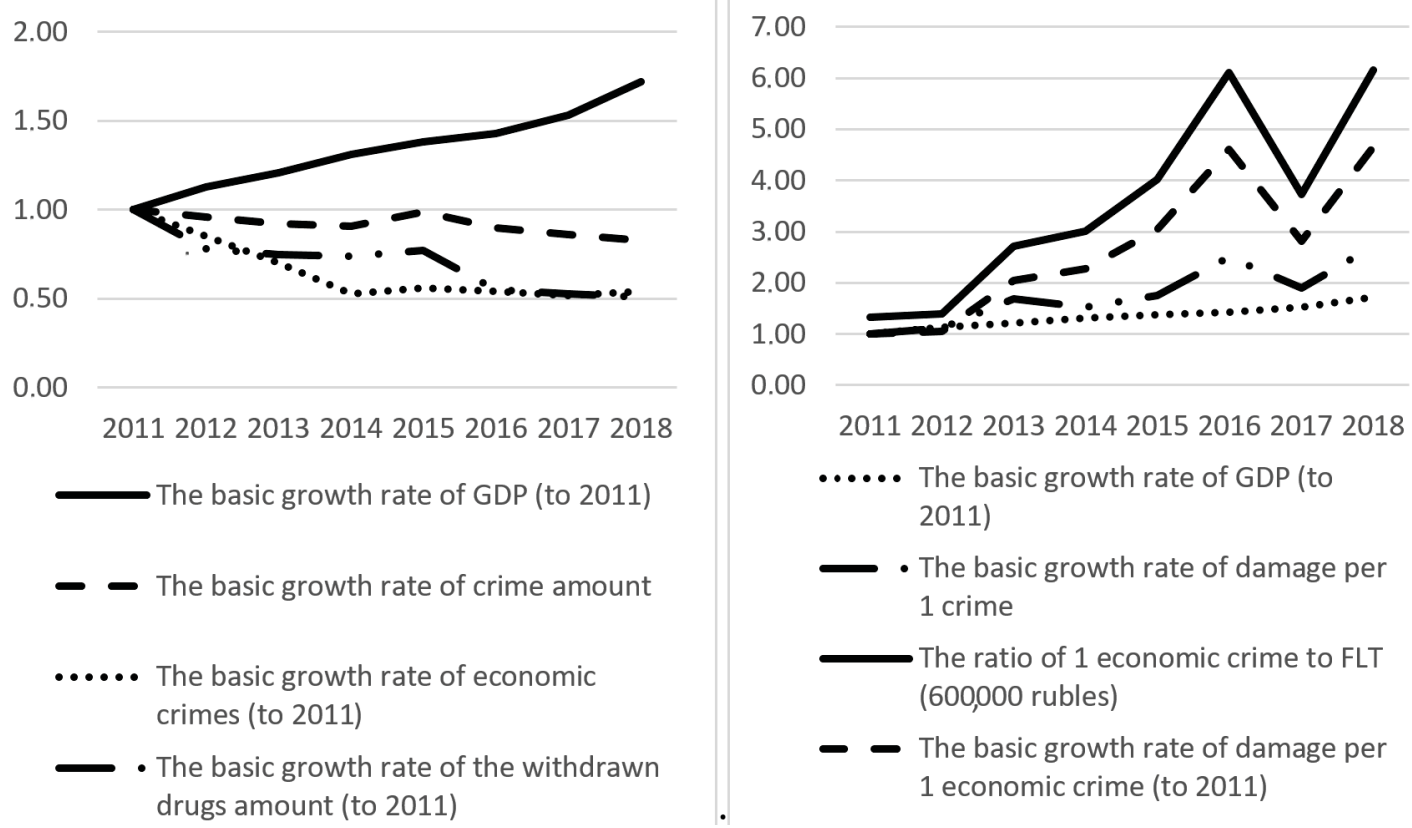

Source: Gross Domestic Product, 2020. Federal State Statistics Service. URL: https://www.gks.ru/accounts (In Russ.); Crime. Ministry of Internal Affairs of the Russian Federation, 2020.

URL: https://мвд.рф/Deljatelnost/statistics (In Russ.)

\section{References}

1. Becker G. Crime and Punishment: An Economic Approach. Journal of Political Economy, 1968, vol. 76, no. 2, pp. 169-217. Stable URL: https://www.jstor.org/stable/1830482

2. Velthoven B.V., Wijck P.V. Becker's Theory on Crime and Punishment, a Useful Guide for Law Enforcement Policy in the Netherlands? Recht der Werkelijkheid, 2016, no. 1, pp. 6-31.

3. Ehrlich I. Participation in Illegitimate Activities: A Theoretical and Empirical Investigation. Journal of Political Economy, 1973, vol. 81, no. 3, pp. 521-565.

Stable URL: https://www.jstor.org/stable/1831025

4. Reynolds M.O. The Economics of Criminal Activity. Introductory Economic. Series Module 12. Andover, MA, Warner Modular Publications, 1973, pp. 1-27.

5. Orsagh T., Witte D. Economic Status and Crime: Implications for Offender Rehabilitation. Journal of Criminal Law and Criminology, 1981, vol. 72, iss. 3, pp. 1055-1071.

URL: https://scholarlycommons.law.northwestern.edu/cgi/viewcontent.cgi? article $=6251 \&$ context $=$ jclc

6. Gutmann P. The Subterranean Economy. Financial Analysts Journal, 1977, vol. 33, no. 6, pp. 26-27. Stable URL: https://www.jstor.org/stable/4478078

7. Feige E. How Big is the Irregular Economy? Challenge, 1979, vol. 22, iss. 5, pp. 5-13. URL: https://doi.org/10.1080/05775132.1979.11470559 
8. Tanzi V. The Underground Economy in the United States: Annual Estimate, 1930-80. Staff Papers (International Monetary Fund), 1983, vol. 30, no. 2, pp. 283-305.

URL: https://doi.org/10.2307/3867001

9. Tanzi V. Macroeconomic Implications of Money Laundering. In: Responding to Money Laundering, International Perspectives. Amsterdam, Harwood Academic Publishers, 1997, pp. 91-104.

10. Karataev M.V. [Modern trends in criminal proceeds laundering and the Russian specifics]. Bankovskoe delo = Banking, 2011, no. 4, pp. 79-85. (In Russ.)

11. Davydov V.S., Gilinskii Ya.I. [Legalization (laundering) of criminal proceeds: Distinctions as part of organized crime, terrorism and corruption]. Sledovatel' = Investigator, 2008, no. 3, pp. 23-29. (In Russ.)

12. Ionov V.M. [Place and role of cash in global economy: Will cash disappear?]. Den'gi i kredit = Money and Credit, 2016, no. 10, pp. 43-50. (In Russ.)

13. Khiaonarong T., Humphrey D. Cash Use Across Countries and the Demand for Central Bank Digital Currency. IMF Working Paper, 2019, WP/19/46.

URL: https://www.imf.org/en/Publications/WP/Issues/2019/03/01/Cash-Use-Across-

Countries-and-the-Demand-for-Central-Bank-Digital-Currency-46617

14. Ardizzi G., Petraglia C., Piacenza M., Schneider F., Turati G. Money Laundering as a Crime in the Financial Sector: A New Approach to Quantitative Assessment, with an Application to Italy. Journal of Money, Credit and Banking, 2014, vol. 46, iss. 8, pp. 1555-1590. URL: https://doi.org/10.1111/jmcb.12159

15. Serga L.K. [On the approach to the definition of the threshold values in the solution of classification]. Vestnik NGUEU = Vestnik NSUEM, 2012, no. 1, pp. 54-60. URL: https://cyberleninka.ru/article/n/ob-odnom-podhode-k-opredeleniyu-porogovyhznacheniy-v-reshenii-zadachi-klassifikatsii/viewer (In Russ.)

16. Glinskii V.V., Serga L.K. [Nonstable aggregates: Conceptual foundation of statistical study methodology]. Vestnik NGUEU = Vestnik NSUEM, 2009, no. 2, pp. 137-142.

URL: https://cyberleninka.ru/article/n/nestabilnye-sovokupnosti-kontseptualnye-osnovymetodologii-statisticheskogo-issledovaniya/viewer (In Russ.)

17. Kanao K., Hamori S. The Size of the Underground Economy in Japan. Economics Bulletin, 2010, vol. 30, no. 1, pp. 893-902.

\section{Conflict-of-interest notification}

I, the author of this article, bindingly and explicitly declare of the partial and total lack of actual or potential conflict of interest with any other third party whatsoever, which may arise as a result of the publication of this article. This statement relates to the study, data collection and interpretation, writing and preparation of the article, and the decision to submit the manuscript for publication. 